In Focus

\title{
Is COVID-19 on the Covers of Socio-Political Magazines an Example of Media Polarisation? Case Study from Poland
}

$\$$ sciendo 
Keywords: media polarisation, COVID-19, magazine covers

\section{ABSTRACT}

The main purpose of this paper was to explore the media image of the COVID-19 pandemic through the perspective of Polish media polarisation. In order to achieve this, a quantitative and qualitative analysis of the content of covers from 10 socio-political magazines, representing different ideological inclinations [left-wing, liberal, conservative, right-wing and Catholic] was conducted between January and June 2020. The study focused not only on the scale to which the coronavirus appeared on the covers, but also on the textual and visual representation of it. Additionally, the contexts in which COVID-19 appeared were analysed. As it turned out, apart from the medical context, the pandemic was mostly presented through political, social, economic and religious perspectives, of which the first was the most visibly connected with polarising media content, indicating clear links between the ideological bias of the magazines and the ways they described reality.

\section{INTRODUCTION}

The media has taken massive interest in the coronavirus. After all, it has made them change the way they function and dominated the content presented to the audience. Naturally, reporting on the epidemic involved non-medical contexts. When functioning within the framework of states and implementing their editorial policies, the media referred to the pandemic according to their own ideologies, activities of authorities, reactions of citizens and various institutions. The question remains open as to whether the media ideological bias was related to the subjectivisation of the COVID19 narrative; that it might be assumed that the coronavirus content should be factbased and emotionally neutral in order to provide reliable knowledge and not lead to a potential escalation of stress or fear.
The Polish media were analysed here because this country is interesting for several reasons. It is politically/socially polarised (Górska 2019: 2) and Polish media are also polarised (Chapman 2017: 7). The main axis of the division is the ideologisation of the media, as expressed by the highly-politicised content, where the ideological bias is identified by criticism (liberal/left-wing media) or support (conservative/right-wing media), including the public media, referred to as the 'propaganda machine' (Reporters without Borders 2020) of the conservative/ right-wing, pro-Catholic, Prawo i Sprawiedliwość (PiS) party.

Also the way the authorities approached the 2020 pandemic is interesting. The first case of the disease was announced on March 4. On March 10, mass gatherings were cancelled, on March 
11, school classes were suspended and on March 12, epidemic emergency was declared. It all happened while there were only 49 cases of COVID-19 noted. Although there was no rapid growth of the pandemic (as in other European countries), further restrictions were tightened on March 20, when the state of the epidemic was introduced. On March 16, the wearing of masks in public places was mandated and on April 1, parks, forests, hotels, beauty services were closed. After a lockdown, on April 20, the guidelines for the "new normality' (the gradual easing of restrictions while maintaining a sanitary regime), were implemented and they were introduced between April 20 and May 30. The easing of restrictions did not take place as a result of the falling number of new cases: on the contrary, in August COVID-19 proved even stronger and the authorities introduced regional restrictions on August 6. In October Poles had to deal with a second, much higher, pandemic wave. Although there are huge numbers of daily confirmed COVID-19 cases [over 12,000 on October 22 alone], not all restrictions from the March-April period have been implemented.

The pandemic has also gained a political context. The main reason for this was the presidential election (planned for May) and a brutal election campaign (Koziński 2020). Other factors included the lack of consistency of those in power regarding the wearing of masks and the irresponsible remarks of politicians. In July the Prime Minister encouraged people to vote for the PiS candidate, informing them the epidemic was in retreat (Maciuszczak, Prus 2020), and scandals arose involving members of the ruling party (e.g. the Minister of Health).

Taking into account the scope of Polish media polarisation, their role during the pandemic and the nature of the pandemic's course, this paper attempts to answer whether the pandemic was the subject of media polarisation and to characterise the media image of COVID-19 in the context of media polarisation.

\section{LITERATURE REVIEW: MEDIA POLARISATION AND MAGAZINE COVERS}

This phenomenon is reflected by Hallin and Mancini, who point out that within the framework of polarised pluralism the media became instruments of political struggle in conflicts between
"dictatorships and by movements struggling against them, but also by contending parties in periods of democratic politics" (2004: 61).

Prior remarked that the media "offer ideologically slanted content"; especially the
"smaller, more specialized, opinion-focused new media out- lets", which "provide the great- est opportunities for one-sided media exposure", offering "more ideologically extreme packages of news and opinion" (2013: 102, 104).

The research by McCluskey and Young provided
"more evidence of polarisation than moderatism (...) suggesting that the 'enduring value' of mod- eratism (...) may no longer apply in the contemporary media and political environment" (2012: 574).

According to them,
"contemporary news values offer reasons for news pres- ence favouring polarisation", and "extremes are more intuitively novel, entertaining, and colourful, representing another common news value" (2012: 576-577).

The phenomenon was also described by Siezieniewska (2014:330), who drew the media division line between elite (informative, with in-depth analyses) and mass (entertaining, lightweight) media and by 
the authors of the "Media Polarisation à la Française" report, who defined media polarisation according to two dichotomies: "institutionalists" vs. "anti-elites" and "traditional" vs. "partisan" (Institut Montaigne 2019: 2).

The theoretical framework of this article is the concept of Gtowacki and Kuś, who defined media polarisation as
"the ways in which different soci- etal and political views, attitudes and behaviours are being both reflected and supported by the media" (2019: 103-104).

In the context of media polarisation the authors offer 4P formula, highlighting the importance of such issues as pluralism, political parallelism, professional journalism and the public. They believe, that
"The question whether media outlets integrate different opin- ions or rather choose one par- ticular societal or political view (partisan media) depends on several systemic factors, such as integration between media and politics (political parallelism) and the strength of journalism culture and accountability (professional journalism). Media polarisation might be supported by the atti- tudes and needs of the public who might want to simply con- sume that news which is close to their own preferences." They con- clude that "all these conditions are interrelated with the state of democracy and its tradition: a weak political culture together with a lack of critical assessment of media content by members of civil society." (2019: 104).

They also specify levels of polarisation both structural and behavioural. The first consists of media policy/regulation, market structure, ownership, financing and governing. Głowacki and Kuś consider that the "response to diversity of political and societal divisions, which usually become more visible in terms of topics which create discussions and controversies (...) might be further manifested in journalistic actions and behaviours" (2019: 104-105).

And that is when the behavioural level of media polarisation appears. It consists of biased reporting, media tribes/media enemy creation and acts of verbal/physical aggression.

It can be said, that the structural level of polarisation is of a systemic nature, resulting from state regulations, as well as the rules of operation of broadcasters and publishers (e.g. editorial policies). Behavioural level of polarisation refers more to the media content and its effects. Among those effects, it is worthwhile to mention misrepresentation of politics (McCluskey, Young 2012: 569), "multiplication of ethical standards” (Głowacki, Kuś 2019: 112), undermining professional solidarity among journalists (Niziołek 2007), "political entanglement of the media” (Figel 2009: 144), lowering of journalistic standards (Szuleka et al. 2019:54), "disproportion of information" handed to recipients (Trzaskowski 2015: 70) or spoiling public debate in that users of polarised media close themselves to different views, seeking sources of knowledge confirming their previous opinions (Prior 2013: 120; Strupiechowska 2018: 147; Jurkowitz et al. 2020). Kotras states that current media discourse "serves to reinforce and deepen isolation" between two opposing camps" (2013: 106), while Morris (2020) notes that "there is a link between certain channels and viewers' inability to connect with or understand members of the opposite political party." As a result, "citizens select media sources that match their ideological bias and obtain a signal that is tailored to that bias" (Gul, Pesendorfer 2012: 3). As Dzięciołowski summarised "ideologically engaged narratives help build a community of like-minded readers" (2016-2017: 41). 
Gentzkow and Shapiro raised the issue of the marketing aspect of the phenomenon, claiming:

\begin{abstract}
"People tend to view an attitudeconsistent news brand as more believable, which induces news producers to bias their content in the direction of their audience in order to sustain the appeal of their brand" (in: Prior 2013: 120).
\end{abstract}

It can be assumed that the above opinion also applies to other media. Such a conclusion is drawn from the research by Brzoza and Kornacka-Grzonka, who stated that political affiliation of socio-political magazines

"...is quite clearly expressed on their covers" (2017: 115).

This statement is important in relation to the subject of this paper. It is common knowledge that covers are a marketing tool, creating the brand image of a magazine (Losowsky 2007: 34; Jenkins, Tandoc 2017: 283), the "magazine's face" (Johnson, Prijatel 1999: 240), or the "magazine's philosophy and identity" carrier (Rosas-Moreno et al. 2013: 3). They perform an informational/ promotional function aiming at creating the

“magazine's brand and expressing its values, allowing the readers to identify it (...) directing the recipients' attention to the content, inviting them to explore it by appropriate selection of cover themes". (Jupowicz-Ginalska 2018a: 106).

If that is the case, then polarised editorial policies - which are examples of structural polarisation - will be expressed in the form of front covers with polarised content designed in such a way as to draw the attention of consumers and to encourage them to buy the magazine.

The ideological bias of a magazine is most fully presented by cover stories (CS), as they systematically reflect the editors' attitude towards the world. They are divided into the main ones (MCS; the most visible: large graphics, noticeable text) and the supporting ones (SCS; less visible, based on text, without or with smaller graphics).

The role of the former ones is to "draw attention to the magazine and encourage people to browse it", while the latter ones - 'to enhance, complete and diversify the message". (Jupowicz-Ginalska 2018b: 5).

\section{METHODOLOGY}

The visible occurrence of the partisan media in Poland is proved by their political parallelism and the lowering of standards of professional journalism, mostly in relation to right-wing media, including magazines, which are the examples of highest degrees of partisan involvement according to Blumler and Gurevitch, 1995. These media are defined by their general pro-government approach. It should be added that liberal and left-wing media, despite their not uncritical attitude towards the government opposition, are clearly against the ruling party, thus also politicised). These observations are supported by weakening political culture (e.g. departing from the principles of the rule of law or undermining equality of all citizens) and a lack of critical assessment of media content since Poland is divided into socio-political tribes each 'owning' its own media that radically attack opponents. Taking this into consideration it can be assumed that all conditions for media polarisation have been met.

Bearing in mind that Polish media are ideologically split, choosing the research sample was based on the structural level of media polarisation (because of its systemic nature), expressed by media editorial policies (as a specific example of media policies).

The final research sample (Table 1) consisted of Polish printed socio-political weeklies. It should be stressed once again that most of the selected media have 


$\begin{array}{ll} & \text { Ideological bias: } \\ & - \text { left-wing (L) } \\ \text { Religiousness: } & - \text { liberal (LI) } \\ \text { - Catholic media (CM) } & - \text { centrist (C) } \\ \text { - secular religious media (SRM)* } & \text { - conservative (CO) } \\ \text { - secular non-religious media (SNRM) } & \text { - right-wing (R) }\end{array}$

\begin{tabular}{|c|c|c|}
\hline Polityka $(P)$ & SNRM & $\mathrm{LI} / \mathrm{L}$ \\
\hline Newsweek Polska (NP) & SNRM & LI \\
\hline Sieci (S) & SNRM & $\mathrm{CO} / \mathrm{R}$ \\
\hline Tygodnik Powszechny (TP) & SRM & C/LI \\
\hline Przeglad (Prze) & SNRM & $\mathrm{L}$ \\
\hline Gazeta Polska (GP) & SNRM & $\mathrm{CO} / \mathrm{R}$ \\
\hline Do Rzeczy (DRz) & SNRM & $\mathrm{CO} / \mathrm{R}$ \\
\hline Gość Niedzielny (GN) & $\mathrm{CM}$ & $\mathrm{CO} / \mathrm{R}$ \\
\hline Idziemy (I) & $\mathrm{CM}$ & $\mathrm{CO} / \mathrm{R}$ \\
\hline Tygodnik Solidarność** (TS) & SNRM & $\mathrm{CO} / \mathrm{R}$ \\
\hline
\end{tabular}

TABLE 1. Categorisation of the selected weeklies. Source: personal collection

1. Describing the scale and manner of presenting COVID-19.

2. Describing the presentation of COVID-19 in the context of media editorial policies (structural polarisation) and textual/visual content (behavioural polarisation) a) How can the media presentation of COVID-19 be characterised?

b) In what kind of contexts was COVID-19 most often presented?

a) Was there a link between the editorial policies of the media (their policies) and the way the pandemic was presented (did structural polarisation imply behavioural polarisation)?

b) Did COVID-19 topics polarise the media?

TABLE 2, Research goals and questions. Source: personal collection 
recently taken a radical political stance. Left-wing and liberal magazines usually criticise the government, while the rightwing and conservative ones support it (e.g. almost directly encouraging voting for the representatives of that party). This division is studied not only by academics (like Mielczarek 2018; Jakóbczak 2019: 249, Głowacki and Kuś 2019), but also confirmed by journalists themselves. One of them even claims that the media "passionately fight each other - in the name of the political and cultural war between Poland and Poland" (Gtowacki 2019). These ideological divisions are enhanced by financial issues, another element of the structural level of media polarisation. In fact, within last few years the right-wing media have received higher advertising revenues due to the support of state companies; whereas, liberal and left-wing media have gained lesser support; (Sikora, 2017).

Table 2 presents detailed research goals and questions for this paper. Its major aim is to analyse how the structural level of media polarisation is reflected in behavioural modes in the context of COVID-19 (in terms of media tribes/media enemy creation, acts of verbal/ physical aggression and biased reporting, when the latter ones mean reporting in extremely subjectivised and/or radicalised way).

No hypothesis was formulated as the research was of an exploratory nature.

The research method adapted was the quantitative-qualitative, comparative content analysis (Pisarek 1983; Lisowska-Magdziarz 2004), carried out on the weeklies' CS.

Within the research process, covering the period January-June 2020, verbal and visual references to COVID-19 from CS were coded (keywords such as pandemic, epidemic, COVID-19, disease, vaccine, infection, doctors, hospitals, remoteness/ mobility, crisis, plus direct or metaphorical visual symbols).

The analysis, apart from aggregating informational data, focused on thematic contexts: medical, political, social, economic, religious, culture, sport and selfpromotion. The CS were coded by the author of this paper. The first version of the data set was completed in mid-July, checked in mid-August and revised as necessary. The final version of the data set was prepared on 22/08/2020.

\section{RESULTS AND DISCUSSION General Data}

In total 1444 CS (300 MCS, 1144 SCS) were published: 232 referred to the pandemic (55 MCS, 176 SCS). COVID-19 was mentioned in all the magazines (Table 3 ). The virus was therefore an ever-present theme, either as a primary or secondary content. The disease was first mentioned in February (in SCS), focusing on its origin, scale and whether it was going to hit Poland. At the end of March and in April, the coronavirus dominated the covers (in MCS and SCS). In mid-May, the media interest in it decreased, but it did not disappear. COVID-19 appeared in GN, I, NP, P, Prze, S, and TP (in SCS).

\section{Thematic Contexts}

Table $\mathbf{4}$ presents the results for the thematic contexts analysis.

The medical perspective most often appeared in the liberal weeklies. The political context was hardly taken up by religious magazines. The social context dominated in liberal magazines, Prze and TP. The liberal media, DRz and TS were more likely to mention the economy. Religious issues were highlighted in the religious weeklies. Some publications (S, DRz, $P$ ), reached out for self-promotion; highlighting the uniqueness of the content.

Specific thematic categories have been singled out within the most popular contexts to further explore the links between media polarisation and COVID-19

\section{(Table 5).}

\section{The Medical Context}

The most frequent theme was the course of the disease. The magazines tried to answer questions such as "Why is the coronavirus so dangerous?" (NP, 6-SCS); "Epidemic of fear. Are we really being threatened by new, deadly diseases?" (P, 6-MCS); "How long will the epidemic last? Three scenarios" 


\begin{tabular}{|c|c|c|c|c|c|c|}
\hline Magazine & CS & CS-COVID-19 & MCS & MCS- COVID-19 & SCS & SCS-COVID-19 \\
\hline$P$ & 240 & 50 & 30 & 12 & 210 & 38 \\
\hline$N P$ & 125 & 34 & 30 & 6 & 95 & 28 \\
\hline S & 148 & 26 & 30 & 6 & 118 & 20 \\
\hline$T P$ & 195 & 23 & 30 & 4 & 165 & 18 \\
\hline Prze & 147 & 19 & 30 & 6 & 117 & 13 \\
\hline GP & 98 & 19 & 30 & 7 & 68 & 12 \\
\hline$D R z$ & 153 & 18 & 30 & 5 & 123 & 13 \\
\hline GN & 112 & 20 & 30 & 4 & 82 & 16 \\
\hline 1 & 136 & 12 & 30 & 1 & 106 & 11 \\
\hline TS & 90 & 11 & 30 & 4 & 60 & 7 \\
\hline
\end{tabular}

TABLE 3. CS (MCS, SCS) - quantification. Source: personal collection

\begin{tabular}{|c|c|c|c|c|c|c|c|}
\hline 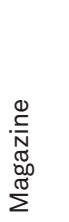 & 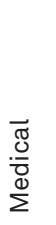 & $\begin{array}{l}\overrightarrow{\widetilde{J}} \\
\stackrel{.0}{ \pm} \\
\stackrel{0}{0}\end{array}$ & $\begin{array}{l}\bar{\pi} \\
\frac{\pi}{0} \\
\infty\end{array}$ & 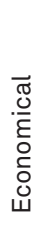 & 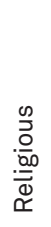 & 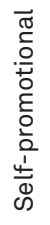 & 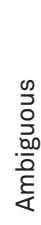 \\
\hline$P$ & 15 & 9 & 7 & 8 & 4 & 6 & 2 \\
\hline$N P$ & 14 & 4 & 8 & 6 & 1 & 1 & 3 \\
\hline S & 10 & 12 & 2 & 0 & 2 & 14 & 3 \\
\hline GP & 9 & 6 & 2 & 1 & 1 & 2 & 2 \\
\hline TP & 7 & 4 & 6 & 3 & 6 & 2 & 0 \\
\hline GN & 4 & 2 & 5 & 2 & 8 & 5 & 0 \\
\hline Prze & 3 & 6 & 8 & 2 & 0 & 0 & 0 \\
\hline$D R z$ & 2 & 8 & 4 & 4 & 3 & 6 & 0 \\
\hline TS & 2 & 2 & 3 & 4 & 1 & 1 & 0 \\
\hline 1 & 2 & 1 & 3 & 1 & 7 & 0 & 0 \\
\hline
\end{tabular}

TABLE 4. CS thematic contexts on COVID-19.

Source: personal collection 


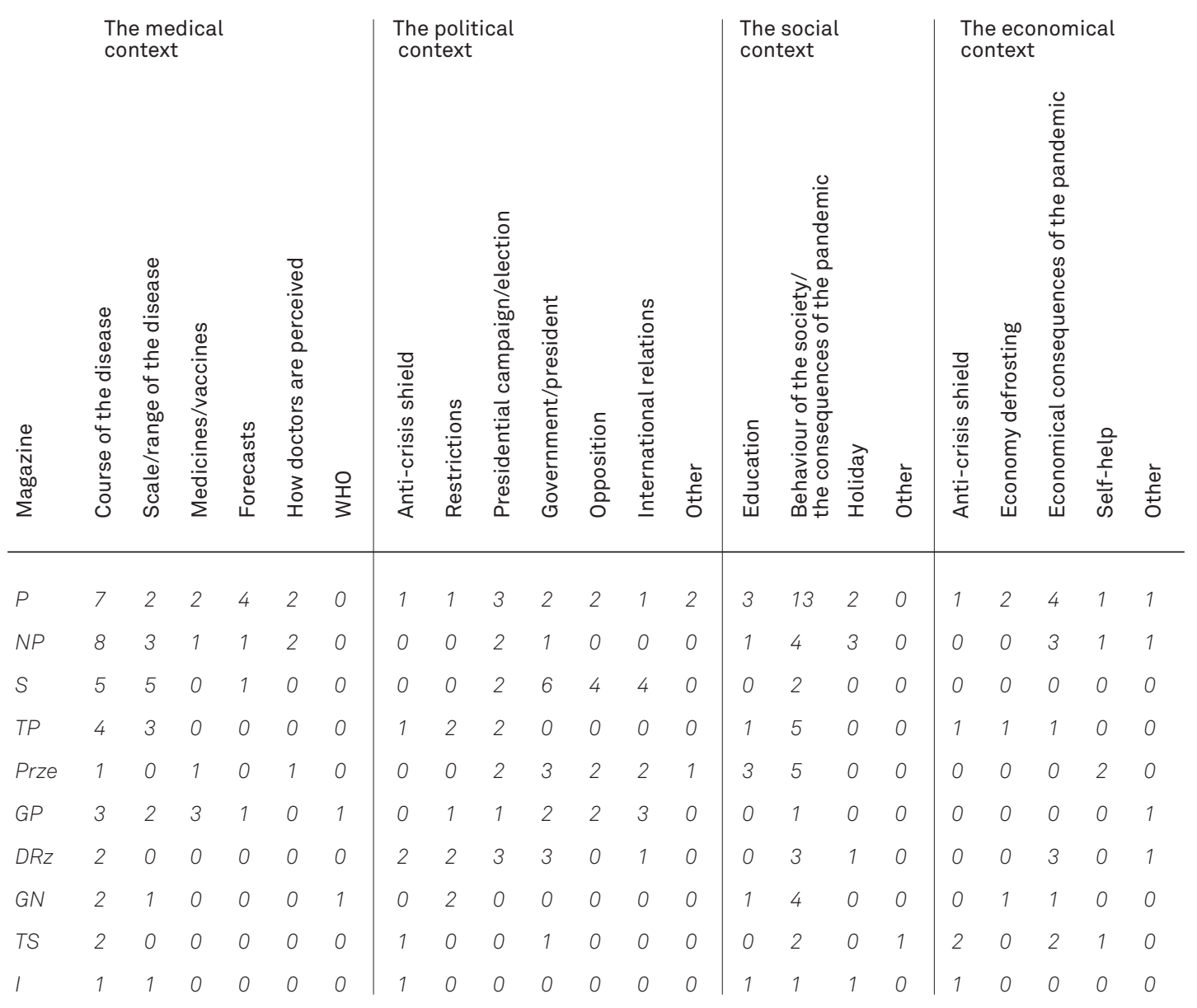

TABLE 5. Categories of contexts.

Source: personal collection 
(S, 14-SCS); "The Swedish way to deal with the pandemic. How does it work?" (S, 16-SCS); "Where the curve is falling: from the Czech Republic to Colombia" (TP, 21-SCS).

The magazines also described the fight against the epidemic in articles such as "Professor Gielerak: a latent virus and half an hour to save a life" (GP, 15-SCS); "Saved from the plague" (I,10-SCS); "(...) Lonely dying of coronavirus" (NP, 23-SCS), "Reports from the isolation" ( $P, 22-S C S)$; "What is it like to get ill with COVID-19. Moving stories" (S, 18-SCS); "Against the pandemic: reports from the four corners of the world" (TP, 14-SCS).

They also gave advice or examples of those who helped others. In "Coronavirus [a practical guide]", GP, 18-SCS; "How to avoid coronavirus - advice from Minister Szumowski" (GN, 11-SCS). S described a senator from the PiS, who "did not hesitate a moment when there was a shortage of doctors in hospitals" and "came to the rescue" (next to the photo of the senator as a politician, there were photos of the senator as a doctor, wearing a protective suit. 14-MCS).

When reporting on the extent of the pandemic, the weeklies indicated its scale, e.g. "The end of the world as we know it" (NP, 12-SCS); "Professor Krasnodębski: how the epidemic will change our world" (S, 18-SCS); "Ways to deal with the virus. From trust to rigour - as many countries, as many strategies" (TP, 17-18-SCS). There were also references to China, e.g. "Wuhan the city where the coronavirus appeared" (GN, 6-SCS); "Virus from China. In the age of big cities there will be more epidemics" (TP, 13-SCS). S also asked about the origin of the virus: "Biological weapon or freak of nature? China kept information about the coronavirus hidden from the world for weeks. That is why many people do not believe in the official version" (MCS-17).

To a lesser extent, the magazines referred to the treatment of the disease, its future and the image of health care (these themes were almost abandoned by the Catholic media).
In the first case, the media reported similarly about medicines/vaccines, the role of hygiene (additionally GP highlighted Poland's success in fighting the virus, writing about a discovery of Polish chemists; MCS-13). In the second case, the magazines foresaw the end of the epidemic or its remission. In the third case, the liberal and left-wing media reported on problems in the health care sector, such as "The hospital that does not listen to the Minister" (NP, 19-SCS); "Hospitals of fear. Healthcare collapse causes more victims than COVID" ( $P$, 17-SCS), "Medics like lepers" (NP, 18-SCS); "Doctors like lepers" (P, 18-SCS); "Antivaxxers threaten doctors" (Prze, 23-SCS).

The conservative right-wing media referred to $\mathrm{WHO}$, questioning its relevance (GN, 18-SCS) and calling its chairman "a liar, a communist, a favourite of China and Russia" (GP, 15-SCS).

Medical CS were accompanied by emotional texts and images (medics, protective clothing, vials, pills, hospitals). The media involved the visualisation of the coronavirus itself. As a recurring logo, it appeared on the covers of DRz (16-SCS), GP (16-SCS) and S (14-MCS, 14-SCS). Its modified form appeared e.g. in TP (10-SCS, instead of spikes it had sprouts), P (18-MCS: a couple looks at the red sky with a COVIDlike sun shining; 19-MCS: President Andrzej Duda wears a COVID-shaped crown); TS (18MCS, a nun in a heroic pose flies between coronavirus-alike logos). Using non-medical symbols of the pandemic gave the message a wider meaning, highlighting the political and social impact of the disease.

\section{The Political Context}

It appeared most often with regard to the presidential campaign/elections and issues concerning the government, the president and the opposition ${ }^{1}$. The greatest interest in

1 The elections were scheduled for $10 / 05 / 2020$, just after the end of the national lockdown. The opposition called for postponement of the elections. PiS, from which the president/candidate for the second term of office came from, did not intend to step down. It planned to organise postal voting (despite the lack of appropriate legislation). In the midst of subsequent scandals, the government decided to postpone the election until June. 


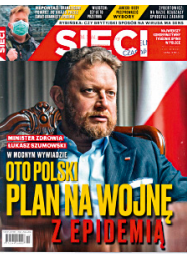

\begin{tabular}{|c|c|c|}
\hline$D R z$ & $\begin{array}{l}\text { "The minister versus the virus. Who is Łukasz Szumowski, head of the } \\
\text { Ministry of Health? Plus the Do Rzeczy report: presidential elections } \\
\text { later? The plagues devastating Poland in the past; How have crises } \\
\text { affected the economy?" (12-MCS). }\end{array}$ & Pof \\
\hline GP & $\begin{array}{l}\text { "You will only hear the truth from me. My patient is the whole of Poland, } \\
\text { we have a chance to reduce the spread of infections." (12-MCS) }\end{array}$ & 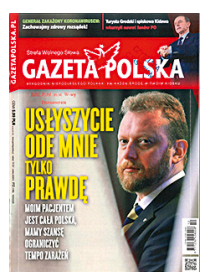 \\
\hline
\end{tabular}

TS "I do not deal with politics; I deal with the epidemic" (16-MCS)

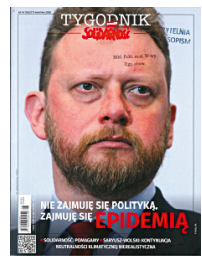

NP "Łukasz Szumowski. Can these eyes be lying? He considers
contraception to be a violation of the Decalogue, he is friends with
Morawiecki, and he chats about boxing with Kaczyński. Who is the
minister responsible for fighting the coronavirus?" (17-MCS)

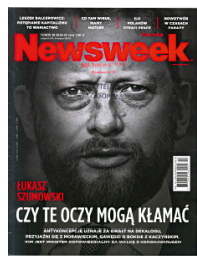

Prze “Łukasz Szumowski: the minister of health or propaganda?”(18-MCS)

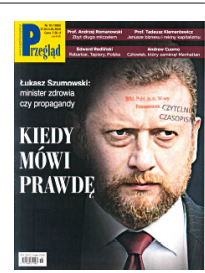

TABLE 6. Minister Łukasz Szumowski in the CS - examples. Source: personal collection 
"We are exposing the opposition's dangerous plan. This is how they want to destroy the elections. The aim is to create chaos. It is supposed to prevent an effective fight against the crisis and bring them to power. They will not give up on anything" (16-MCS).

Politicians affiliated with the opposition party Platforma Obywatelska. Left to right: Borys Budka, Małgorzata Kidawa-Błońska (the presidential candidate at the time), Donald Tusk.

\begin{tabular}{ll}
\hline$D R z$ & "How is Platforma using the epidemic to their own advantage" \\
(14-SCS). & "Interview with Prime Minister Morawiecki. An opposition president \\
would hinder the fight against the coronavirus" (22-MCS).
\end{tabular}

GP "Jaśkowiak and Czarzasty: boors in the time of plague (13-SCS)".

Jacek Jaśkowiak - the liberal mayor of Poznań; Wtodzimierz Czarzasty a left-wing politician.
P "Coronation? Recipe for election" (19-MCS).
President/candidate Andrzej Duda (PiS), consequently supporting the government's policy.

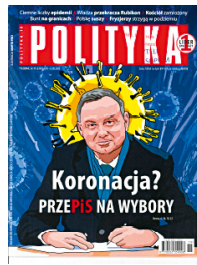

Prze "Elections in May is lunacy" (13-MCS).
President Andrzej Duda.

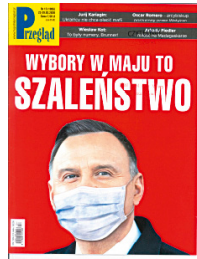


them was shown by the conservative-right media, but also $P$ and Prze. The pro-Catholic magazines did not address it.

One of the main figures in the political theme was the Minister for Health, Łukasz Szumowski. Table 6 shows how he was presented on the covers of the magazines. There was a noticeable discrepancy between the conservative/right-wing and liberal/left-wing media. The former showed the minister in a positive light: as a politically neutral specialist, hinting at his medical education. The photographs were in bright colours, and apart from the portraits (of a tired but respectable and focused man), there were symbols - the Polish flag and the logo of the Ministry of Health. The liberal and left-wing weeklies doubted Szumowski's depoliticisation (raising his conservative views and close relations with prominent PiS politicians) and the sincerity of his actions. That was accompanied by gloomy portraits with dark colours.

Differences between the magazines can also be seen in the way the election topic was presented (Table 7). Here the media consistently implemented their editorial policies.

The right-wing conservative weeklies were on the government's side, supporting the May election date and claiming that the opposition president "would hinder the fight against the crisis" (GP, 22-MCS). They fiercely attacked the opposition and implied that it was using the disease as a tool to seize power. The liberal, left-wing media and TP adopted opposing positions. They called for the elections to be postponed, emphasising the safety of voters. They accused the government of stubbornness, and - after the announcement of a new election date - of a lack of transparency in communicating this decision. They were neutral towards the opposition.

All the weeklies used conspicuous means of visual and linguistic expression. They strengthened the message through neologisms, epithets and metaphors (like a letterbox, which - depending on the ideological bias of the magazine - symbolised either the fight for the May elections or the crusade against them). The liberal magazines were more likely to use sublime irony, while the conservative and left-wing magazines preferred to use blunt language.

The international perspective on COVID-19 is also worth mentioning. The liberal and Catholic media rarely raised this topic, but the right-wing and conservative media, in line with their critical attitude towards the EU, envisaged its weakening, emphasised Poland's strong position towards Russia and developed coronasceptic theories (DRz: "Warzecha on coronavirus denialists. Are we fighting COVID-19 using too radical methods?", 16-SCS; GP: "Will the EU survive? A famous American analyst describes the world after the pandemic"; 18-MCS). On the visual level, explicit symbolism appeared, for instance, a closed padlock and photographs of world leaders or the drowning EU flag.

\section{The Social Context}

Two main themes appeared here: fear/ anxiety and a sense of community/loneliness/mental problems/breaking/adjusting to restrictions. The media similarly approached anxiety/fear, pointing out that the coronavirus affects physical and mental health, causing large-scale panic/ psychosis. Almost all the weeklies treated this topic negatively; either bluntly (Prze, "Between fear and panic"12-MCS), or metaphorically. For example the scattered word \#Polacy on the cover of NP was a symbol of a broken, digitalised society (16-MCS), while a mask on the face of the screaming person from the Munch painting (TS, 11-MCS) intensified the feeling of danger. TP broke out of the convention, soothing the message of fear with "common sense" and replacing the spikes of the virus with green sprouts (imagining a chance for revival, 10-MCS). DRz succumbed to corona-scepticism, asking "How we succumbed to fear. COVID-19: pandemic or psychosis?" (23-MCS).

The weeklies differed slightly in terms of the sense of community/loneliness/mental problems/restrictions. GN focused on community building, support and a positive motivating message ("In Gość: we are doing 
well, we as a society are passing the test"; 13-SCS).

The liberal media spoke in a similar spirit of adapting to the "new normality" (NP, 13-MCS, P, 16-MCS) as well as TP (13MCS) and TS (18-SCS). The latter weeklies (apart from TS) highlighted the negative aspects of the pandemic, though loneliness (P, 15-MCS; TP, 16-MCS, Prze, 20-SCS) and life disorganisation (NP, 10-SCS). Some of the magazines raised the issue of government restrictions, wondering about their lifting (S, 18-SCS) or proving that after a long period of lockdown Poles are consciously giving them up ( $P, 20-S C S, 21-S C S)$. $P$ indicated the hardships of the "new normality" (22-MCS), and referred to attempts to fit in as "manoeuvring."

The media also reported other social effects of COVID-19; writing about cancelled weddings ( $P, 15-S C S)$, generation conflicts ( $P, 16$-SCS), the epidemic of "virus divorces" (NP, 29-SCS) and an "epidemic of violence" (Prze, 20-MCS). These consequences of the pandemic were only noticed by the liberal and left-wing magazines.

The gap between the media also emerged with regard to education. The conservative-right weeklies did not refer to this issue, and the Catholic ones presented it neutrally. The liberal and left-wing magazines were quite critical of remote education coordinated by the government. NP sneered: "The virus? Who cares, we have final exams" (17-SCS), P wrote about the "nightmare of home lessons" (20-SCS), and Prze mentioned the "e-fiction of Minister Piontkowski” (25-SCS). A similar narrative was adopted by TP: "An un-remote school. Equal and more equal students." (28-SCS).

As far as the visual side of this thread is concerned, the common denominator seems to be the virtual world, which enabled human contact during the lockdown (mobile phones, video conferences, masks also appeared).

\section{The Economical and Religious Context}

All the magazines anticipated negative economic consequences of the pandemic, predicting the second Great Depression
(DRz, 12-MCS; 19-MCS), inflation (12-SCS), higher taxes (TP, 16-SCS), unemployment (TS, 17-SCS; NP, 15-SCS), company bankruptcies and the collapse of healthcare $(P$, 16-SCS, 17-MCS).

Other themes included economy defrosting (GP, 17-SCS; P, 17-SCS; TP, 20-SCS) and grassroots initiatives such as struggle for survival (NP, 20-SCS; P, 19-SCS; TS, 14-SCS). The magazines disagreed slightly on the issue of the government anti-crisis shield. The conservative-right and Catholic weeklies viewed it positively or neutrally, while $P$ described it as "leaky" (14-SCS), and TP indicated its shortcomings (14-SCS).

Despite the last observation, the economic theme was presented in a factual way, focusing on the analysis of the state of the economy during and after the lockdown.

Regarding the religious context, the right-wing and Catholic magazines wrote about the faith either neutrally $(D R z$, 15-SCS; 14-SCS) or positively (DRz,13-14SCS; TS, 18-MCS; GP, MCS-15), with the latter raising more issues, e.g. the Easter season, changes in administering holy sacraments and the clergy's fight against the pandemic. They also quoted Church officials and highlighted the role of faith/ prayer in getting stronger, e.g. "The patroness of Europe. In times of crisis, calamities and plague, Saint Catherine proved that those who faithfully obey God can amaze the world" (GN, 17-MCS). Interestingly, the magazines saw the brighter sides of the pandemic: the chance for conversion and the de-commercialisation of Easter (GN, 19-MCS, 26-SCS).

TP maintained a balance of opinion; saw hope in faith, but also noticed problems related to it, e.g. spreading disease in churches (16-SCS) or economic issues (16-SCS). The liberal magazines distanced themselves from the subject, and addressed it quite rarely. The religious theme did not appear in Prze.

\section{CONCLUSIONS}

A description of the scale and manner of presenting COVID-19 on the covers of 
ideologically biased socio-political weeklies (RG1) was provided. The frequency with which the coronavirus thread appeared in CS (RQ1a) was indicated, including their chronological distribution.

All the media referred to the pandemic, but to different extents. The liberal weeklies wrote about the pandemic most often, while $I$ and TS wrote about it most rarely. The coronavirus enjoyed the greatest interest of the magazines in the period of March-April. Afterwards, interest was decreasing, which could be related to the presidential election campaign.

The contexts in which reference was made to the pandemic (RQ1b) were also indicated. The most popular were: medical, political, social, economic and religious ones. The last appeared also on the covers of secular magazines. Its popularity is not surprising as Poland is a Catholic country where faith and its practices were important issues during the epidemic; Bożewicz 2020:3).

The research material collected was also analysed in terms of the relationship between the media editorial policies and the ways in which the epidemic was presented (RG2).

The structural level of media polarisation, represented by different ideological bias of the magazines, resulted with the behavioural polarisation in some of the analysed thematic contexts (RQ2a, b). The relationship between the two levels of media polarisation was clearly noticeable in the political context, where the media image of the Minister for Health and the electoral threads were radicalised.

In other contexts it was more difficult to imply the media polarisation. The medical theme focused mostly on the disease without ideologising it. There were only a few exceptions including the right-wing media criticising WHO, aggressively calling its chief "a communist" and binding him with Russia and China. This approach can be connected with the hostility of these media to all manifestations of left-wing ideology (or even more so communism), but also with the desire to divide the world into 'our' and 'theirs' (China became the antihero of several right-wing media covers). It is also worth mentioning that right-wing media did not really mention about crisis in Polish health care system (as it was ruled by rightwing government).

In the social context, the weeklies did not differ when they referred to anxiety/fear. Traces of polarisation could be observed in the areas of education and community/ loneliness/mental problems/restrictions. There were even some signs of coronascepticism in right-wing media, but - what is interesting - they appeared in June, close to the date of the first round of the presidential election).

The economic context did not significantly polarise either (except in relation to the government anti-crisis shield).

In the religious context the differences can be observed in the number of CS presenting COVID-19 through the angle of faith, but it cannot be considered as the evidence for media polarisation.

It can be said that the magazines usually published coronavirus content according to the established editorial policies, which was evident in the scale and specificity of the contextualisation of CS.

The behavioural level of media polarisation was expressed by biased reporting which could result with creating the enemy through visual/verbal means of expression. No media tribes creation was observed, but it was not much needed to become one: representing the opposite party or simply China would be enough. Undoubtedly, it was the political context that brought radical differences between the studied media, and the division was intensified by presidential elections (RQ2b).

Taking the above considerations into account, it can be assumed that the problem analysed here fits into the current research trends of media polarisation, according to which politics is one of the major flywheels for this phenomenon. This paper does not, therefore, prove the emergence of new types of polarisation, but empirically confirms that in COVID19 case left-wing and liberal media were 
against right-wing government and rightwing media were pro-government.

On the other hand, however, it shows that medical, economic and religious threads can also be studied in the context of media polarisation. It is true that in these areas media spoke about COVID-19 in a similar spirit, but it can be assumed that this situation would change with issues linked to more controversial world views and ideologies (for example, abortion, euthanasia or contraception).

The media mostly used metaphors, epithets, exclamations, neologisms and questions. The language sphere was emotional and engaged, referring to combat, with the conservative-right weeklies using bluntness slightly more often. The liberal and Catholic weeklies were more likely to use either neutral or more sophisticated means of expression, also in the visual layer. The pandemic was referred to either directly (as a coronavirus logo - traditional or modified, images of hospital equipment and protective clothing, doctors) or indirectly (photographs or images of saints, maps of Europe). Symbolism also appeared, with references to Polish national colours, images of flames, crosses, the globe and a new symbol: the letterbox. Colours were also important, which - depending on the message formulated - strengthened the message either positively (green) or negatively (black, grey, red).

This paper has certain limitations. Only the covers of magazines were studied - they were chosen as the subject of analysis deliberately because of their significant functions. It must be admitted, however, that the front pages do not present their medium's editorial policies, but only metaphorically and briefly mention them. They cannot be treated as the full emanation of the medium's editorial policy. Further research in this area would, therefore, require deepening, i.e. analysis of entire articles announced on the covers by CS. It would also be interesting to see how the media image of COVID-19 was shaped by television, radio and the internet. The research sample was also based on media representing opposite ideologies (which reflected the structural level of media polarisation). In the future, it might be worth examining how the pandemic was referred to in the typical centric media. 


\section{REFERENCES}

Adamski, Andrzej; Jupowicz-Ginalska, Anna; Leonowicz-Bukała, Iwona 2020. 'Polish Nationwide Catholic Opinion-Forming Weeklies on Social MediaFrom Theoretical Introduction to Empirical Approach'. Religions 11, 4,190. DOI: https://doi.org/10.3390/ rel11040190.

Bartoszewicz, Mateusz 2017. 'Komunikaty populistyczne na okładkach tygodników „Newsweek Polska” o "Do Rzeczy” - raport z badań pilotażowych'. e-Politikon 24, 87-111.

Blumler, Jay; Gurevitch, Michael 1995. The Crisis of Public Communication. $1^{\text {st }}$ Edition, Florence, US: Routledge, 2002.

Bożewicz, Marta 2020. 'Wpływ pandemii na religijność Polaków. Komunikat z badań CBOS'. https://cbos.pl/ SPISKOM.POL/2020/K_074_20.PDF (8 August 2020). Brzoza, Katarzyna; Kornacka-Grzonka, Momika 2017. 'Narracja medialna wyrażona na okładkach wybranych tygodników opinii podczas parlamentarnej kampanii wyborczej 2015 roku'. - Polityka i Społeczeństwo 4, 15, 100-116.

Chapman, Annabelle 2017. 'Pluralism Under Attack: The Assault on Press Freedom in Poland'. https:// freedomhouse.org/sites/default/files/FH_Poland_ Report_Final_2017.pdf (6 September 2020). Dobek-Ostrowska, Bogusława 2018. 'Mediatyzacja polityki w tygodnikach opinii w Polsce - między polityzacją a komercjalizacją?. - Zeszyty Prasoznawcze 2, 234, 224-246. DOI 10.4467/22996362PZ.18.016.9111 Dzieciołowski, Krzysztof 2016-2017. 'Is there a chance for non-partisan media in Poland?'. Reuters Institute Fellowship Paper - University of Oxford (6 September 2020).

Gentzkow, Matthew; Shapiro, Jesse, M. 2006. 'Media bias and reputation'. - Journal of Political Economy 114, 2, 280-316.

Gtowacki, Witold 2019. 'Tym razem ustawą o dziennikarzach'. - Polska The Times, September https:// polskatimes.pl/pis-znow-probuje-wziac-sie-za-mediatym-razem-ustawa-o-dziennikarzach-program-pisna-wybory-parlamentarne-2019/ar/c1-14425529 (22 October 2020).

Głowacki, Michat; Kuś, Michał 2019. 'Media accountability meets media polarisation. A case study from Poland'. - Eberwein, Tobias; Fengler, Susanne; Karmasin, Matthias (eds.), Media Accountability in the Era of Post-Truth Politics. Routledge, 100-115.

Górska, Paulina 2019. 'Polaryzacja polityczna w Polsce. Jak bardzo jesteśmy podzieleni'. http://cbu.psychologia. pl/uploads/f_bulska/Polaryzacja\%20 polityczna\%202. pdf (6 September 2020).

Gul, Faruk; Pesendorfer, Wolfgang 2012. 'Media and Policy [Working paper]'. Department of Economics, Princeton University. http://www. princeton. edu/ pesendor/media.pdf (23 October 2020).

Guzek, Damian 2019. 'The Church-State Relationship in Polish Media: Combining the Grounded Theory and Intermedia Agenda-Setting at the Network Level'. Polish Sociological Review 208, 439-457.

Hallin, Daniel C.; Mancini, Paolo 2004. Comparative Media Systems. Three Models of Media and Politics. Cambridge: Cambridge University Press.

Institut Montaigne 2019. 'Media Polarization "à la française"?'. https://www.institutmontaigne.org/ressources/ $\mathrm{pdfs} /$ publications/media-polarization-a-la-francaisereport.pdf (6 September 2020).

Jakóbczyk, Natalia 2019. ‘Obraz szczytu NATO w 2016 roku w Warszawie na łamach tygodników społecznopolitycznych'. - Rafał Klepka, Jakub Idzik (eds.), Medialne obrazy świata, t. 2. Kraków: Wydawnictwo naukowe Uniwersytetu Pedagogicznego, 231-251. Jenkins, Joy; Tandoc, Edson C. 2017.' The power of the cover: Symbolic contests around the Boston bombing suspect's Rolling Stone cover'. - Journalism 18, 2 , 281-297. https://doi.org/10.1177/1464884915614240.
Johnson, Sammye; Prijatel, Patricia 1999. The Magazine form cover to cover. Lincolnwood: NTC Publishing Group.

Jupowicz-Ginalska, Anna 2018a. 'Print magazine covers as packaging'. - Communication Today 9, 1, 94-112. Jupowicz-Ginalska, Anna 2018b. 'Exposure of Travel Destinations on the Front Covers of the Magazines National Geographic Traveler and Podróże'. - Journal of Tourism and Services 9, 17, 1726-54. https://doi.org/10.29036/jots.v9i17.44.

Jurkowitz, Mark; Mitchell, Amy; Shearer, Elisa; Walker, Mason 2020. 'U.S. Media Polarization and the 2020 Election: A Nation Divided', January 24.

https://www.journalism.org/2020/01/24/u-s-mediapolarization-and-the-2020-election-a-nation-divided/ (6 September 2020).

Kotras, Marcin 2013. 'Dwa światy, dwie narracje. Retoryka tygodników opinii W Sieci i Polityka'. - Acta Universitatis Lodziensis, Folia Sociologica 46, 89-109. Koziński, Agaton 2020. 'Wybory prezydenckie 2020: Dobry zły i brzydki. To była najkoszmarniejsza kampania w historii'. - Polska The Times, 10 July. https://polskatimes.pl/wybory-prezydenckie-2020dobry-zly-i-brzydki-to-byla-najkoszmarniejsza-kampania-w-historii/ar/c15-15071494 (6 September 2020). Lisowska-Magdziarz, Matgorzata 2004. Analiza zawartości mediów. Przewodnik dla studentów. Kraków: Uniwersytet Jagielloński.

Losowsky, Andrew 2007. 'Hold the front page'. - Andrew Losowsky (ed.), We Love Magazines. $1^{\text {st }}$ ed. Luxembourg: Editions Mark Koedinger SA, 33-42.

Maciuszczak, Tomasz; Prus, Katarzyna 2020. 'Premier do seniorów: nie bójcie się koronawirusa. A w weekend w woj. lubelskim 24 nowe przypadki'. - Dziennik Wschodni, 3 July. https://www.dziennikwschodni.pl/ wybory-prezydenckie/premier-do-seniorow-nie-bojciesie-koronawirusa-a-w-weekend-w-woj-lubelskim24-nowe-przypadki,n,1000269633.html (6 September 2020).

McCluskey, Michael; Young, Kim M. 2012. 'Moderatism or Polarization? Representation of Advocacy Groups' Ideology in Newspapers'. - Journalism \& Mass Communication Quarterly 89,4, 565-584. https://doi.org/10.1177/1077699012455385 Mielczarek, Tomasz 2018. Tygodniki opinii w zmieniającej się rzeczywistości. Kraków: Towarzystwo Autorów i Wydawców Prac Naukowych Universitas. Morris, Catherine (2020). 'Polarized Media Landscape Mirrors Polarized Public.' https://www.ipsos.com/en-us/ media-polarization-mirrors-polarized-public

(6 September 2020).

Niziołek, Andrzej 2007. 'W okopach'.

https://wiadomosci.onet.pl/kiosk/w-okopach/wdg6d (6 September 2020).

Pisarek, Walery 1983. Analiza zawartości prasy. Kraków: Ośrodek Badań Prasoznawczych.

Prior, Markus 2013. 'Media and Political Polarization'. The Annual Review of Political Science 16, 101-27. DOl: https://doi.org/10.1146/annurev-polisci-100711135242

Reporters without Borders 2020. 'Poland: Further decline'. https://rsf.org/en/poland (6 September 2020) Rosas-Moreno, Tania C.; Harp, Dustin; Bachmann, Ingrid 2013. 'Framing ideology: How Time magazine represents nationalism and identities through visual reporting. - Communication and Society/Comunicación y Sociedad 26, 3, 1-20.

Sikora, Kamil 2017. 'Te liczby szokuja. Nawet 1900 proc. więcej na reklamy państwowych firm w prawicowej prasie'. - Wp.pl, 4 July. https://wiadomosci. wp.pl/te-liczby-szokuja-nawet-1900-proc-wiecej-nareklamy-panstwowych-firm-w-prawicowej-prasie6140609609774721a (23 October 2020).

Strupiechowska, Monika 2018. 'Media jako katalizator społecznych lęków. Przypadek paniki moralnej'. - Media i Spoteczeństwo 8, 139-150. 
Szuleka, Małgorzata; Wolny, Marcin; Kalisz, Maciej

2019. 'Rządy prawem zamiast rządów prawa: zagrożenia

dla ochrony praw w Polsce w latach 2015-2019'.

http://obserwatoriumdemokracji.pl/wp-content/

uploads/2019/10/Rz\%C4\%85dy-prawem-HFPC.pdf

(6 September 2020).

Trzaskowski, Paweł 2015. ‘Różne sposoby mówienia

o mowie nienawiści w polskich dziennikach' -

Studia Pragmalingwistyczne VII, 69-83.

Tygodnik Przegląd 2020. 'O Przeglądzie'.

https://www.tygodnikprzeglad.pl/o-przegladzie/

(6 September 2020). 